\section{B A Institute of \\ YK Business Administration \\ 帘 \\ Karachi \\ Leadership and Ideas for Tomorrow}

Business Review

Volume 10 Issue 1 January - June 2015

$1-1-2015$

\title{
EasyPaisa: Seizing the white space and business model innovation
}

Nasir Afghan

Institute of Business Administration, Karachi, Pakistan

Follow this and additional works at: https://ir.iba.edu.pk/businessreview

Part of the Business Intelligence Commons, Finance and Financial Management Commons, and the Technology and Innovation Commons

(c) (7)

This work is licensed under a Creative Commons Attribution 4.0 International License.

\section{Recommended Citation}

Afghan, N. (2015). EasyPaisa: Seizing the white space and business model innovation. Business Review, 10(1), 147-166. Retrieved from https://doi.org/10.54784/1990-6587.1320

This article is brought to you by iRepository for open access under the Creative Commons Attribution 4.0 License and is available at https://ir.iba.edu.pk/businessreview/vol10/iss1/12. For more information, please contact irepository@iba.edu.pk. 
https://ir.iba.edu.pk/businessreview/vol10/iss1/12

DOI: https://doi.org/10.54784/1990-6587.1320

Business Review - Volume 10 Number 1

January - June 2015

CASE STUDY

\title{
EASYPAISA: SEIZING THE WHITE SPACE AND BUSINESS MODEL INNOVATION
}

\author{
Nasir Afghan \\ Institute of Business Administration, Karachi, Pakistan
}

\begin{abstract}
Easypaisa is a diversification case study written about two very different organizations, a Telco and Microfinance Bank, and howthey merged to create a new business. This new business was providing MobileFinancial Services. Both Telenor (a Telco) and Tameer Bank (Microfinance bank) saw a business opportunity in branchless banking (business white space). They were committed to make this acquisitionsuccessful, where Telenor bought over 51\%sharesof Tameer Bank. However, as per regulations, the branchless banking model is to be governed under a bank-led model. Therefore, the face of Easypaisa has always been Tameer Bank which is expected to manage all the regulatory issues and compliance issues and back end processes while Telenor uses its vast distribution network and marketing skills to create a winning business model.

The case provides opportunities for students to explore Easypaisa business model generation and how they capture the white space beyond existing market and business model. Case also looks future challenges from Telenor and for Tameer Bank point of views. The success of Easypaisa brings new opportunities and complexities for Telenor and for Tameer Bank top management.
\end{abstract}

Key words: Easypaisa, Business Model Innovation, Business White Space, Mobile Money, Branchless Banking and Business Leadership.

\section{Introduction}

It was Friday, 15 ${ }^{\text {th }}$ February, $2013 \mathrm{Mr}$. Nadeem Hussain was gazing out at the skylines of Shahrah-e-Faisal, Karachi from his office glass window. He was reflecting on his Micro Finance bank known as Tameer Micro Finance Bank. He founded the bank in 2004 from his (\$ 6 million) life savings of around \$6 million collected from a job at Citi Bank. In 2008 he became a pioneer part of the kick-start of branchless banking in Pakistan through a branchless banking service called Easypaisa. However, through his decision he received a lot of speculation as many thought that he was gambling with his life savings. On the other hand Mr. Omer, Head of Strategy Easypaisa at the Telenor head office in Islamabad, was thinking how sustainable the current business model of Easypaisa actually is? The question that concerned him the most pertained to the new regulations imposed on Mobile Banking in Pakistan. What if the new regulations imposed by the State Bank change the playing field from One-to-One Model to Many to Many Model? What then should be the strategy and action plan in taking Easypaisa forward?

Despite all the negativity and doubt in October 2009 Easypaisa was launched with its first product of enabling Utility Bill Payments followed by a Money Transfer service. This service went on to winning several awards including the award for the best product in 2010 and 2012. In 2010 Easypaisa won the award for 'Best Mobile Money Transfer Entrant of the Year' at the world's first Mobile Money Transfer (MMT) Awards held in Dubai. The very 
next year the service was pitted against some of the world's leading mobile financial service providers, and it was also the only service nominated by the jury in three of the six categories. In 2012 Easypaisa was yet again nominated for two awards: "Most Inventive Marketing Campaign" and "Achievement in Financial Inclusion".

Mr. Nadeem was more than satisfied with the Easypaisa's achievements but as he thought about the future of Tameer Bank, his face became serious. The question that was worrying Mr. Nadeem was that what Tameer Bank's future strategy for the next two years should be? Which avenues should be focused upon to guarantee success for the bank and how? How should he manage the perception of the bank as microfinance bank and not merely as a commercial money transfer bank?

Since the Easypaisa launch in October 2009 there had been nearly 130 million transactions worth more than USD 2.9 Billion till June 2013. Also June 2013 experienced almost 200,000 transactions daily through the Easypaisa system. Every month almost 4 million new consumers started to use Easypaisa services because of the trust, convenience, accessibility, reliability, and security of transaction it provided. At present, the Easypaisa team stood at a moderate size of 200 employees from both the Tameer (Karachi) and the Telenor Group (Islamabad).

\section{Global and Local Context of Mobile Money Business}

According to the statistics provided by the International Telecommunications Union in the table below, the total number of cellular subscribers in the world had approximately reached six billion in 2011 .

Table 1: details of Mobile cellular subscriptions by International Telecommunications Union ${ }^{1}$

\begin{tabular}{|l|l|l|l|l|l|l|l|}
\hline \multicolumn{2}{|l|}{ Mobile-cellular subscriptions (millions) } \\
\hline & 2005 & 2006 & 2007 & 2008 & 2009 & 2010 & 2011 \\
\hline Developed & 992 & $1^{\prime} 127$ & $1^{\prime} 243$ & $1 ' 325$ & $1^{\prime} 384$ & $1^{\prime} 413$ & $1^{\prime} 514$ \\
\hline Developing & $1^{\prime} 215$ & $1^{\prime} 619$ & $2^{\prime} 126$ & $2^{\prime} 706$ & $3^{\prime} 263$ & $3^{\prime} 898$ & $4^{\prime} 457$ \\
\hline World & $2^{\prime} 207$ & $2^{\prime} 747$ & $3^{\prime} 369$ & $4^{\prime} 031$ & $4^{\prime} 647$ & $5^{\prime} 311$ & $5^{\prime} 972$ \\
\hline
\end{tabular}

Given that the world population is slightly above seven billion, the table depicts that there is very little room for further growth in cellular subscriptions. Another important fact to note, after studying this table, is that almost $97 \%$ of the global population growth in 2012 came from developing countries ${ }^{2}$. Hence, given the already high penetration of cellular services in these regions and the high growth rate of both the cellular market and the regions' population, there rose a need to develop cellular services in such developing economies.

As shown in the figure 1, the global growth rate of payment transactions of mobiles mobile payment has increased by an average of $68 \%$ annually till 2012 . Where the total market for mobile payments was transacting at $\$ 28.9$ billion back in 2008, by 2012 this amount shot up to $\$ 249.1$ billion. As depicted in the figure, this growth rate, in 2012 , was at $56 \%$ in developed markets while being $20 \%$ higher in emerging markets.

1. http://www.itu.int/ITU-D/ict/statistics/at_glance/KeyTelecom.html

2. http://www.prb.org/Publications/Datasheets/2012/world-population-data-sheet/factsheet-world-population.aspx 
Figure 1: Arthur D. Little analysis ${ }^{3}$ of Mobile Industry Growth.

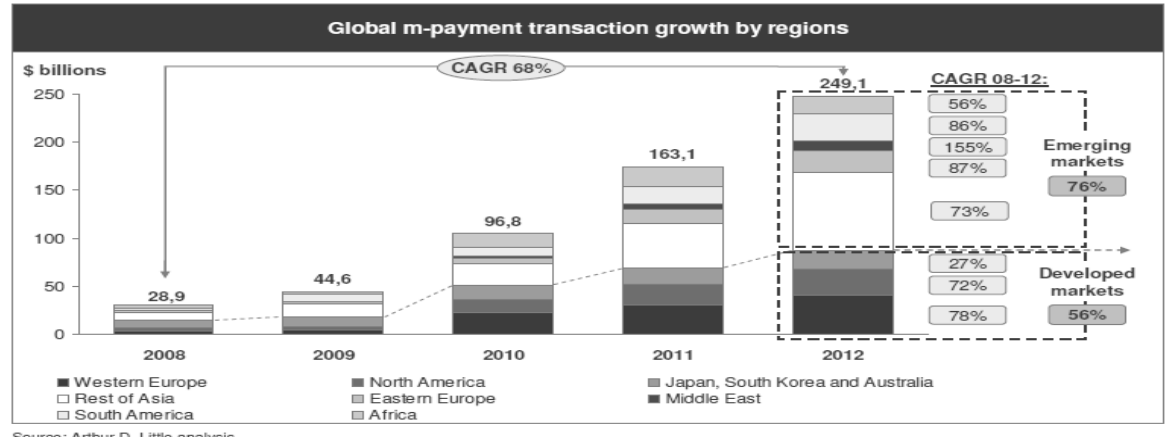

\section{Mobile Banking Scenario in Pakistan}

Keeping in mind that Pakistan has a population of about $180+$ million, with around 15-20 million bank accounts, Mr. Habib Ali at Tameer Micro Finance Bank Limited said, "In Pakistan, there are currently an estimated 30 million economically active people who have no access to basic transactional services, let alone savings and other financial safety net solutions. Now, with Easypaisa, these people can have a bank account without a physical bank branch and can conduct financial transactions from the comfort of the home by using just a basic cell phone." He further said, "The World Bank estimates a domestic (i.e. within Pakistan) transfer volume at close to $\$ 7$ billion a year. Through Easypaisa, we aim to target current users of domestic remittance services. Also, we aim to help bring a portion of the $\$ 2$ billion to $\$ 4$ billion transacted through informal channels into the mainstream."

Figure 2: Details on unbanked Pakistan (source: http://www.telenor.com.pk)

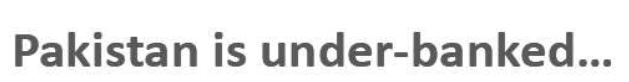

\section{easypaisa}

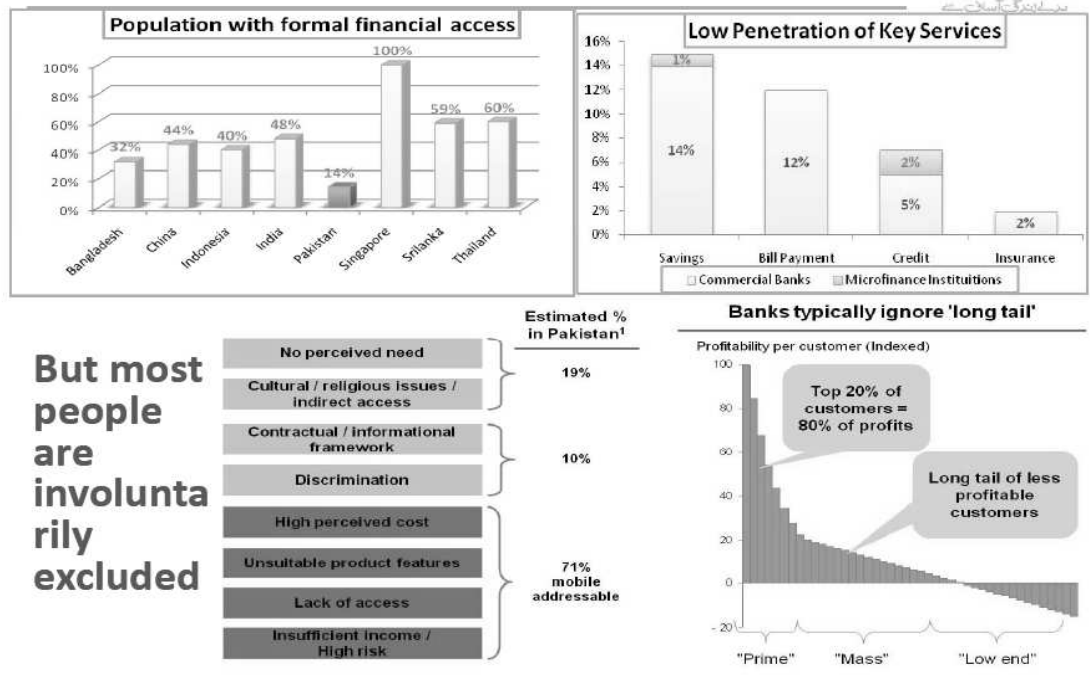

3. http://www.telecomcircle.com/2011/01/the-mobile-payment-conundrum/ 
As depicted in figure 2 above, Pakistan is clearly lagging in financial out reach. The graph depicts a low penetration of key services shows that only $15 \%$ of the entire Pakistani population has access to formalized saving channels, $12 \%$ have access to utility bill payment services and only $5 \%$ and $2 \%$ have availability of credit and insurance respectively. Since there are around 11,000 bank branches therefore there is limited access to banking services.

Since 2004, the number of mobile service providers has been increasing hence showing that the outreach of mobile services is far more than that of financial services. Table 2 below shows some numbers for cellular subscribers from 2003 to 2012 that depict this scenario:

Table 2: Annual Cellular Subscribers from 2004 to 2012 (Source: http://www.pta.gov.pk)

\begin{tabular}{|c|c|c|c|c|c|c|c|}
\hline \multicolumn{8}{|c|}{ Annual Cellular Subscribers } \\
\hline & Mobilink & Ufone & Zong & $\begin{array}{l}\text { Insta } \\
\text { phone }\end{array}$ & Telenor & Warid & Total \\
\hline 2003-04 & $3,215,989$ & 801,160 & 470,021 & 535,738 & & & $5,022,908$ \\
\hline 2004-05 & $7,469,085$ & $2,579,103$ & 924,486 & 454,147 & 835,727 & 508,655 & $12,771,203$ \\
\hline 2005-06 & $17,205,555$ & $7,487,005$ & $1,040,503$ & 336,696 & $3,573,660$ & $4,863,138$ & $\mathbf{3 4 , 5 0 6 , 5 5 7}$ \\
\hline 2006-07 & $26,466,451$ & $14,014,044$ & $1,024,563$ & 333,081 & $10,701,332$ & $10,620,386$ & $63,159,857$ \\
\hline 2007-08 & $32,032,363$ & $18,100,440$ & $3,950,758$ & 351,135 & $18,125,189$ & $15,489,858$ & $88,019,812$ \\
\hline 2008-09 & $29,136,839$ & $20,004,707$ & $6,386,571$ & 34,048 & $20,893,129$ & $17,886,736$ & $94,342,030$ \\
\hline 2009-10 & $32,202,548$ & $19,549,100$ & $6,704,288$ & 0 & $23,798,221$ & $16,931,687$ & $99,185,844$ \\
\hline 2010-11 & $33,378,161$ & $20,533,787$ & $10,927,693$ & $\mathbf{0}$ & $26,667,079$ & $17,387,798$ & $108,894,518$ \\
\hline Dec-11 & $34,213,552$ & $21,368,744$ & $13,874,709$ & $\mathbf{0}$ & $28,130,720$ & $15,287,861$ & $112,875,586$ \\
\hline Mar-12 & $35,787,527$ & $23,120,657$ & $15,663,398$ & $\mathbf{0}$ & $29,348,228$ & $14,397,106$ & $118,316,916$ \\
\hline May-12 & $36,048,127$ & $23,550,270$ & $16,566,768$ & 0 & $29,896,660$ & $13,798,974$ & $119,860,799$ \\
\hline
\end{tabular}

In Table 2 it is evident that numbers of cellular subscribers are reaching an optimum with very slow growth rate.

However, in Table 3 below it is evident that the incremental growth in the mobile popularity in terms of Teledensity has increased by over 20 times in a period of 7 years or so.

Table 3: Annual Teledensity from 2004 to 2010 (Source: http://www.pta.gov.pk).

\begin{tabular}{|c|c|}
\hline \multicolumn{2}{|c|}{ Annual Cellular Mobile Teledensity (\%) } \\
\hline Year & Mobile Density \\
\hline $\mathbf{2 0 0 3 - 0 4}$ & 3.29 \\
\hline $\mathbf{2 0 0 4 - 0 5}$ & 8.30 \\
\hline $\mathbf{2 0 0 5 - 0 6}$ & 22.21 \\
\hline $\mathbf{2 0 0 6 - 0 7}$ & 39.94 \\
\hline $\mathbf{2 0 0 7 - 0 8}$ & 54.60 \\
\hline $\mathbf{2 0 0 8 - 0 9}$ & 58.20 \\
\hline $\mathbf{2 0 0 9 - 1 0}$ & 60.4 \\
\hline
\end{tabular}


According to one consultant in the telecom industry, "The future challenge for telecommunication operators in Pakistan will be how to provide financial services to the unbanked population." In an interview (DAWN, February 20, 2013) Mr. Roar Bjaerum said, "Our challenge is how to have 100,000 distribution points and bring 50 million people into banking services by 2020. If we succeed in doing so, we will increase new jobs in Pakistan by 1 million and will increase the GDP growth rate of the country by $3 \%$." He further said, "The challenge is how to convert people from using risky, insecure and fraudulent informal channels (like Hundi / Hawala) systems and, in doing so, bringing cash into formal banking sector thereby helping the government in minimizing the risk of illegal activities that help finance terrorists and also promote money laundering."

\section{What are the causes of financial exclusion?}

According to a report by Telenor, "Financial exclusion predominates in the world's emerging economies often as a result of lack of credit history, overly complicated financial products, limited access to banking branches and little trust in the existing financial institutions. The 2.5 billion unbanked people manage to work around the system by, for example, borrowing or loaning between friends and family, obtaining short-term credit from employers, forming illegal savings clubs or seeking out illegal moneylenders. These options are often risky, costly and with indeterminate results".(source: http://www.telenor.com.pk)

"The mobile phone is emerging as a key tool for bringing financial services to unbanked populations. It allows users to complete basic payments and remittances via the mobile phone, and gives easier access to savings, credit and insurance products," said Jon Fredrik Baksaas, President and CEO of Telenor Group. He continues, "We as a telecom company have a unique advantage in being able to provide mobile financial services to the unbanked population. We have a pre-established relationship with the customers, who already have mobile devices in their hands and we are a trusted and established brand in the regions we operate, with a large and secure distribution network". (Source: http://www.telenor.com)

While it is widely agreed that mobile financial services are positively affecting emerging economies already, Telenor and $\mathrm{BCG}^{4}$ explored what the picture will look by the year 2020. According to BCG report estimates, mobile financial services may result in a 5-20 percent reduction of financial exclusion by 2020. In Pakistan alone, the reduction may be as much as 20 percent.BCG report estimates that mobile financial services have the power to increase gross domestic product (GDP) by up to five percent by 2020. This GDP growth may be stimulated by increased access to credit, which prompts new business creation, as well the benefits of formal remittances and increased savings (Source: http://www.telenor.com).

\section{A tool for societal change}

With mobile financial services reaching a potential of 341 million people in the study conducted by BCG for Telenor, the report further says, "By 2020 there is bound to be some significant social impact which will lead to increasing access to healthcare and insurance, better opportunities for women through access and control funds and the encouragement of transparency through fewer cash."

4. The Socio-Economic Impact of Mobil Financial Services: Analysis of Pakistan, Bangladesh, India, Serbia and Malaysia, April, 2012, the Boston Consulting Group, USA. 
The BCG report specifically explored the financial burdens experienced by families during times of disaster, looking into how mobile financial services could provide some relief. They found that mobile financial services serve as an important tool for responding and preparing for natural disasters. A solution such as Telenor and Tameer Bank's Easypaisa can be used as a means to solicit and distribute donations for example. According to Mr Baksaas President and CEO, Telenor Group, "While BCG's perspective on mobile financial services seems to be promising, we must also be ready to face a few hurdles along our way to a financially inclusive 2020. The consumers must be educated, a distribution network and business model must be in place and the approval of the regulators must be gained. These steps are vital for the successful spread of financial services, and Telenor will continue to face these challenges in creating more services that improve the quality of life for our customers." He further added, "We are just scratching the surface. There is a long road ahead and the possibilities are endless like offering international money transfers, B2B and B2C transactions, micro-insurance and many more. Our product development team is constantly exploring new services and solutions to meet all the needs of Easypaisa users." (Source: http://www.telenor.com)

\section{Business White Space for Telenor and Tameer Bank}

Telenor believes that ARPU (Average Revenue Per User) in the GSM (Global System for Mobile Communication) is decreasing day by day. Initially all the GSM players when entering the market were of the thought that the GSM business has huge potential. However after having 6 different players enter the market, price wars were initiated which resulted in price cuts making the average ARPU which used to be $\$ 18-20$, at the emergence of the GSM market, to be less than $\$ 2$ or $\$ 3$ a month now thereby depicting a very low figure.

In early 2008 the idea of using cell phone for payments and to transfer money was unbelievable and it was unconvincing that Telenor group could be able to develop this concept into a new revenue stream. However, people had started to spend a greater part of the day with their cell phones. This societal and behavioral change caught the telco managers' attention and this observation lead them to start thinking on how to avail this new opportunity and introduce a service that could help the consumer to pay bills and also transfer funds.

The chief idea behind Easypaisa was to enable transactions through mobile in a country like Pakistan where $15-16 \%$ people have access to banking channels and around 84$85 \%$ people have no formal access to banking channels. The main objective of State Bank for allowing branchless banking was to introduce financial inclusion and provide access to these people. According to the State Bank, in Pakistan, there were around 15 million active bank accounts whereas Telcos had 120 million subscribers which depicted there was a huge gap between financial services and Telcos. This means that at that time, Telcos had enough reach to provide for financial inclusion in this market. Although there were still 3 players in the market, there was huge potential and a lot of capacity available to provide for financial inclusion.

According to the State Bank of Pakistan, the idea of branchless banking through using mobile phones can enable the unbanked population to become a part of the banking system. Of the 100 million adult population in Pakistan, 15 million are banked which leaves behind 85 million people as a part of the target market for such a service. If these 85 million save only 2 thousand rupees, then on annual basis they save around 3 trillion rupees and these 
are still those people who are already in the subscriber base. There are still people in rural areas that are outside of the coverage area of Telcos. The biggest advantage we had was that when we got the license back in 2004-05 we found out that there are already very big players in the urban market, so we started from rural and we expanded equally in rural and urban regions. Mobilink and Ufone did not have a high presence in the rural areas because they only focused on the major cities. We had the largest footprint in Pakistan in rural areas, whereas Mobilink had not made that much of an impact in these regions."

For this futuristic idea several studies were conducted to study the money transfer and payment trends. After sufficient observation and data had been collected, Telenor decided to enter into financial business. However, the forming of Easypaisa was not smooth-sailing. The State Bank of Pakistan did not allow any Telco to have their own bank or to conduct any financial transactions and hence had created regulations that stated that in order to establish a branchless banking model the proposed structure should be a bank led model.

According to Mr. Nadeem, these regulations resulted in the acquisition of $51 \%$ shares Tameer Microfinance Bank. The Telenor Management had been involved in the planning behind this move for a whole year and in the process they had meetings with various banks. They found out that to acquire a big bank they had to either do a joint venture with them or had to purchase some stake in them. However, the product they planned to bring to the market required them to have a say or control in such alliances. However, this business management mind-set of Telenor conflicted with that of most banks. Another reason why the Telenor Management's mind-set conflicted with other banks was because Telenor's subscriber base is huge whereas in banking the subscriber base was low but with high revenue streams. This difference could neither be understood by GSM companies nor banks as the mind frames and cultures of both types of businesses are so different. Hence, their alliance is very difficult primarily because of a difference in focus; banks traditionally focus on deposits (corporate clients and few big customers) while Telcos focus on all customer be they small or big.

Telenor decided that instead of signing MoU and having separate managements, they should stick to acquiring majority shares in a bank. Hence, Tameer was the best available option because of two reasons: firstly because bigger banks like, Habib Bank Limited, Muslim Commercial Bank had unjustifiably very high share prices while Tameer was a new and innovative bank and thus, had low share prices. Secondly, Tameer's vision matched with that of Telenor because their President, Nadeem Hussain, was a very dynamic person. Though having started his career from CITI Bank, he had a very different vision from other bankers. Although the first microfinance bank was Khushhali bank, Tameer bank surpassed it in 2006 by becoming the first branchless micro-financing bank. Tameer bank pushed this idea and somehow managed to convince SBP. In conclusion, Telenor went to Nadeem and told him that we will buy stakes in his bank and the alliance between Tameer and Telenor was hence formed.

Mr Nadeem remembers that he was a bit apprehensive about this deal. He says, "The deal was not easy for us, they wanted to buy the bank and SBP (State Bank of Pakistan) was not allowing more than $51 \%$ shares to be sold. In order to convince them, I invited the both Governor of State bank and CEO Telenor for a meeting and after a lengthy discussion it was agreed upon that Telenor will buy $51 \%$ shares of the Tameer bank, a CEO of Tameer bank will be appointed and the alliance will have three directors and a chairman of the bank 
board." The Telenor manager explained, "If we had purchased all of the shares, it would have become a Telco-led model."

The Easypaisa and Tameer alliance is a representation of the "1-to-1" model. Initially the State Bank had only allowed a"1-to-1" model i.e. only one Telco can join hands with one bank. The other models that State Bank has now started to introduce include the "1to-many" which means that 1 Telco can join hands with many banks and vice versa, and "many-to-many" model i.e. all the operators can join hands with all the banks. From the model that Telenor had formed with Tameer, there are around 20,000 agents for Easypaisa which is more than the number of total branches (estimated 11,000) of all banks together in Pakistan and four times the total number of ATM machines in the country.

According to Mr. Omer Moeen, the Head of Strategy at Easypaisa, "When we launched Easypaisa we focused primarily on the bill payment product and consequently domestic remittances. Customers previously used to go the post office to make payments for these two financial services and thus these two primary sources of ours got the best response as they provided convenience and a hassle-free system. Our service made this process very instantaneous. Through the system we introduced, a customer submits cash at the shop, communicates the pass-code, and in a matter of hardly 3-4 minutes the transaction is processed." He further said, "To understand our customers we spent months studying customer daily routine and life style concentrating on what are their day to day issues were and how we can try to resolve them? We had our sleeping bags with us and we would spend nights and days with our customers. We had our ears to the ground to understand and to know what and how we have to do to solve our customers' financial problems. Hence, we were able to design the ideal product, agent channel, distribution and retail network and the front end marketing for Easypaisa."

Telenor's mainly focusing on a target market of people who worked in urban areas but had to send money to rural areas for e.g. people like drivers who work in the city while their families live in rural areas. Previously, such workers used to rely on a completely unreliable and informal system of money transfer by going to the inter-city Bus Station, giving their salaries to bus drivers and then helplessly relying on the bus drivers to reach their villages and give the money to their families. Apart from the risk associated with this kind of money transfer, there were also leakage issues which delayed this money transfer. Furthermore, extra money had to be paid to the bus drivers for conducting this service. With Easypaisa, Telenor also charges money, but the process is instant because the money gets delivered instantly through their network. Easypaisa now has 3-4 million transactions every month where these transactions primarily belong to the same laborers sending back money to their families in rural areas or making bill payments.

Easypaisa has basically two money transfer / payment models: one is the $\mathrm{M}$ wallet through which a consumer can open up a bank account in his/her mobile and the other is the OTC i.e. Over-the-Counter model. In the OTC model, it is not necessary to be a Telenor subscriber. One can simply transfer money by providing a copy of their NIC without opening an account. The charges on the $\mathrm{M}$ wallet are less than those on the OTC service to encourage people to become more self-reliant. Through the $\mathrm{M}$ wallet service though, the customer has been given the liberty to perform money transaction on his/her own rather than going to a shopkeeper/retailer. Hence, the Easypaisa service has been made available to everyone, be they Telenor subscribers or not. 
Talking more on these services, Mr. Roar explained in an interview with DAWN (20 ${ }^{\text {th }}$ Feb. 2013) why the Easypaisa team had put more focus on the OTC service at first. He said, "We made a deliberate choice to focus on OTC transactions at the time of launch because in a country, like Pakistan, where financial inclusion is very limited, it was more prudent for us was to start with the lower hanging fruit, that is why we started with the OTC model and later on moved to promoting the mobile account (M-Wallet)".

Before the team at Telenor decided upon the target customer they had to conduct an extensive research. To identify the target consumer, Telenor researched very thoroughly. They hired some consulting companies and companies associated with mobile money like CGAP (Source: http:/www.CGAP.com) which had done similar related studies which helped Telenor immensely. Telenor also took assistance from Boston Consulting on the existence and identification of mobile financial services opportunity within Pakistan and their benefits and impact on the Pakistani population. The report done by BCG concluded there are two basic financial transactions here which everyone wants to carry out: bill payment and money transfer.

Bill payment is the primary transaction as there is a deadline for their payment every month. Hence the consumer is always short on time and in a hurry to pay his bills on time. The secondary transaction is that of money transfer where heads of families transfer funds to their families residing in rural areas for their monthly expenditure. These two core potential products were highlighted in the research studies through which we could strengthen our brand instead of presenting an entire bouquet of services and then assuming that people would pick and choose from them according to their own needs. Initially Easypaisa faced a lot of problems because people thought that when the management talked about banks and providing a means for financial transactions it would involve stamps and receipts because the concept of branchless banking was unknown. However, the Easypaisa team eventually had to include a stamp in order to gain customer confidence although the electronic confirmation is enough in this model as it contains the customer's transaction ID, amount, the name of the agent who did it and other authentication details. Due to the lack of trust shown by this consumer segment, a stamp and receipt system had to be included. However, at the same time Easypaisa started slowly exploring and strengthening its brand identity in order to gain their trust. Now that the brand is established, the Easypaisa team has decided to offer more products.

The objective of Tameer microfinance was to give small loans to business persons. Easypaisa achieved this objective of Tameer by offering a loan repayment option. Tameer's microfinance business was separate but Telenor is still supporting them in it. Through Easypaisa, two saving variants have recently been introduced: Beema and Munafa. KhushaalBeema offers a hybrid product with a free life and accidental insurance if an individual keeps a minimum of Rs. 2000. This insurance package starts from 50 thousand and goes up to 500 thousand with no charges. KhushaalMunafa offers a premium interest against various minimum slabs.

Mr. Kabeer said, "We essentially focus on small entrepreneurs. Our loans are for people who do small businesses. We don't give loans to very poor people because they can't repay them. However, we don't give loans to rich people either. Our biggest category of borrowers to whom lenders are apprehensive to give loans to is made up of the small businessmen e.g. shopkeepers. Small general stores that stock commodities like tea, milk packs and cigarettes would also be able to stock bread and eggs if given 50,60 or 70 thousand rupees. This is where we come in." 
As depicted in the Tameer Bank Balance Sheet that has a footing of Rs 11 billion, Rs 10 billion throughputs are from the Easypaisa channel alone and hence one can imagine the important role the Easy Paisa channel plays.

In an interview Mr. Roar said, "We faced many challenges in generating the awareness of financial services. For this, we have consistently invested, from the start, in trainings for our Easypaisa shops and for our customers through marketing campaigns and specially designed communication. Hence, the Easypaisa service has continued to evolve and grow in light of such challenges and will continue to provide customized solutions for all its customers". (DAWN, 20 Feb, 2013).

According to Mr. Omar Moeen, the Easypaisa Strategy head, "The implementation of strategy was not so easy and there were many challenges for us. The most important challenge to tackle was the development of the Easypaisa team. Initially, the Easypaisa team was divided in two with the Telenor team in Islamabad looking after the business model, and the Tameer bank team in Karachi looking after the risk and banking side. In the initial phase, the teams had very serious issues with each other and there was time when they even stopped talking to each other. It was a complete disaster! However, the CEO of Telenor intervened and he came to the decision that the Telenor team will spend two weeks in Karachi at the Tameer office and the Tameer Bank team will spend two weeks in Islamabad with the Telenor team. These two weeks rotations were conducted for 8 months and coordination between the two teams improved significantly. The second team building strategy that the CEO of Telenor adopted was to send all of us together to a tea plantation in Sri Lanka for three days. We were there together for three days sleeping in tents and cooking and eating together as one group. After that team building experience our team became one: the Easypaisa team. Now both teams welcome problems and assist each other by resolving one another's issues."

\section{Tameer Bank's Motivation for Branchless Banking}

Initially Tameer Bank faced high costs: the huge salaries to be paid and infrastructure and technology costs. Unfortunately, micro finance is a business of small margins due to small loans and receiving no discounts on any of their cost base. This squeezed the profits even further. To address this concern and making themselves easily accessible to target market, they opened various branches in areas such as Landhi and Baldia town versus more expensive areas such as Shahra-e-Faisal. In the first year, Tameer opened up 13 branches in Karachi in a market which stood at 18 million at that time. They employed 20,000 people and reported zero delinquencies. Hence the first year was concluded with a false sense of hope that being Citi bankers they understood the business and it were able to easily operate it.

However, in 2005 the delinquency ratio started to increase (Exhibit A for Tameer bank financial data). Bad loans were made in the aggressiveness to drive the business growth. Branch managers were approving loans to their maximum limits and any overflow was authorized by the head office to increase sales volume. No attention was being given to secondary checks and balances. Also, debtors were being sanctioned loans through intermediaries whereas the bank, at times, did not even meet the customer. As the delinquencies increased, Tameer started breaching the capital adequacy limit. According to Nadeem, "The results from Tameer, in the second year, taught them that this business was not as simple as it seemed. The business needed the volume but not at the stake of such delinquencies. The controls needed to be strengthened in order for Easy paisa to grow otherwise the business would not breakeven in even 10 years." 
With this lesson Tameer stepped into "Tameer Bank 2.0." The objectives of the Tameer 2.0 were:

- Geographical diversification: To move out of Karachi and diversify the portfolio in Punjab.

- $\quad$ Strengthen upfront processes even if it meant increasing expenses and reduced backend flow.

- Strengthening front end corporate controls which meant starting up on independent customer evaluation and verification process by Relationship Managers

- Set up of a regional credit management committee

- Initiating a courtesy call back process to the customer

With these new control systems in place towards the end of the $2^{\text {nd }}$ year, the bad debts started clearing up and the delinquencies came down from $25 \%$ to $5 \%$ i.e. from Rs $140 \mathrm{~m}$ to Rs. $80 \mathrm{~m}$. Nevertheless, 2006 ended with a breach of minimum capital requirement for the bank. To cover the breach that, Nadeem had to put up an additional million of his personal funds.

By the first half of third year though, it was very clear that the bank needed capital injection. They had successfully maintained geographical diversification, product diversification and implemented safety controls, but in order to survive more cash injection was needed urgently. Given that Mr. Nadeem the entrepreneur had exhausted most of his personal resources and had much at stake, it was time to look at serious cost cutting measures because a significant portion of cost was constituted in maintaining and running branches.

Mr. Nadeem (CEO Tameer Bank) said, "We recognized that we will only be able to reach a significant proportion of our target market only if we find innovative ways of reaching customers outside the expensive and geographically constrained traditional branch infrastructure." He further said, "In 2007, we were requesting State Bank to develop branch less banking regulations and we were the first to embark on it. We then even obtained capacity building grant from Bill and Melinda Gates Foundation (in 2011) to improve our marketing capabilities, enhance agent network and performance via agent training and improving cash management for agents, and to improve business delivery capabilities to serve rural and urban areas through alternative delivery channels."

\section{Telenor's Motivation for Branchless Banking}

Similarly in 2007 and 2008 Mr. Jon Eddy Abdullah, the CEO of Telenor, Pakistan was able to see the declining trends in the industry and decided to develop mobile financial products to capture the gaps between the two industries and aim at meeting some unmet demands.

Following are the gaps that provided incentives for mobile money banking:

- $\quad$ Rural areas as well as lower class people in Pakistan are primarily unbankedthus untapped market: According to a State Bank Report, only 16 percent of the people in Pakistan have access to a formal financial institution.

- Banking is too costly an activity to do in rural areas 'in its current form': Here current format means using traditional branch structure, where a branch would 
consist of minimum 3 employees, 1 guard and one office boy. With minimal accessories, according to rough estimates, a traditional branch would require monthly cost of approx. PKR 1 Million.

- Branches are costly to be built in rural areas: In banking sector, opening more than 4 new branches a year is usually considered as an expansion project owing to the huge amount of investment it involves. Moreover, with the currently depressed economy, banks cannot afford to wait for 3-4 years for a rural branch to breakeven. According to an employee of Bank, "one major bank despite posting second or third highest profits in banking sector for years only 400 out of 1400 branches of this bank are profitable at branch level".

- Telecom sector has reached a saturation point in its traditional format: Telecom sector has reached a point where all competitors have lowered the prices to a level where there is no road downwards. According to some estimates, in 2009, Pakistan generated second largest SMS traffic for approx. 700 million. With per capita income far lower than many other nations, use of SMS at such large level indicates intensity of price war. Now, voice quality and signal strength are no more distinguishing factors, these are the basic requirements. Value added factors introduced so far may become a good fad but their utility is very low and thus revenue generation from them is not sustainable.

- Revenue volatility from value added services: With the intense competition and price war in telecom sector, venturing into a different business model that may give them sustainable stream of revenue.

- Regulatory Requirements: Since 9/11, there has been intense pressure on banks to ensure that they know who their customers are. There has been a complete section dedicated on Know Your Customer (KYC) and Money Laundering. Now the banks require a host of documents to open an account to reduce reputational risk that may happen in case a terrorist financing scam surfaces. (source: Telenor official reports and Interviews)

Designing the Products for Target Audience: After conducting a gap analysis, Telenor decided to design the product in order to deliver the financial services to the unbanked population i.e. mostly for the people at the bottom of the pyramid. Persons from such a background would least likely to go into a bank's branch but rather go more often to the local pan shop or convenience store i.e. he would trust a neighborhood retailer more than a banker in fine suiting. The person at the bottom of the pyramid might have never used internet in his life, but would have at least a basic phone and could at least read numbers. While helplessly preoccupied with earning his daily wages, he might not be able go to a fancy branch of a 9 to 5 bank and wait in line wasting the time he could have used to earn his bread for the day. He would rather go to a local, trusted retailer and pay him for the bill.

Telenor also found out through research that a significant part of this class of people, particularly those living in metropolitan areas, have entire or at least a part of their immediate or extended family in some village who are dependent on their monthly earnings. However, the total value of money that these people have to send to their relatives in villages is too small for to get into the hassle of submitting countless documents in the bank. Moreover, an ordinary person from this class is also not educated enough to provide proper signatures for the authentication process and may face issues from getting his own money back from bank. 
Hence, with this target market profile in mind, Easypaisa was launched itself with a positioning as a as a convenient, accessible, and secure financial solution with no hassles attached to it.

The complete profile for the target audience for Easypaisa included the following:

- Typically males

- $\quad$ Aged between 18 and 50

- Belonging to lower-lower or lower-middle class

- Usually blue collar job-holders or small-scale self-employed individuals

- Little access to formal banks and lack of willingness to do so

- Very busy

- $\quad$ Acquainted to use SMS at basic levels

The following figure provides the profiles of Easypaisa users:

Figure 3: Easypaisa user profile

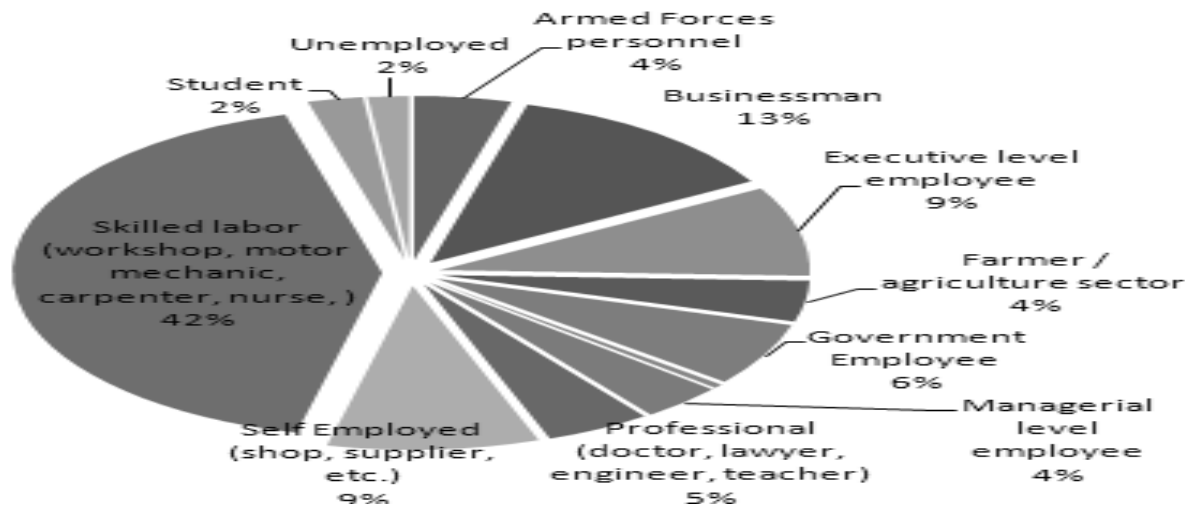

What Easypaisa Offered:

Easypaisa Mobile Account: Easypaisa Mobile Accounts were actual bank accounts and work like a normal bank account except through the mobile phone. This service, however, was only available for existing and new Telenor subscribers. The Easypaisa Mobile Account could be opened from any Telenor Sales and Service Centers, Telenor Franchise or Tameer Bank branch. Using Easypaisa Mobile Account, Telenor subscribers were now able to pay bills, transfer money and use many more services from their own mobile phones, anytime, anywhere.

Donations through Easypaisa Shop: Through the Easypaisa donation service, one could contribute to the society by supporting various causes. Easypaisa took an initiative in this regard by offering donation services that ensured the transfer of donation amounts to different organizations in a secure and reliable manner. Using this service, donation amounts could now be transferred to respective organizations.

Easy.Pay Solution for Companies: Easy.Pay solutions catered specifically to corporate organizations that wanted a convenient and reliable mode of payment collection 
from customers. In availing this service by Easypaisa, organizations were to be provided with a Corporate Easypaisa mobile account number, which they could communicate to their customers. Customers in turn could then make payments to the corporation from thousands of Easypaisa shops all over Pakistan or from their own Easypaisa mobile account. Out of these products, the most commonly Easy.Pay solution used was that of Money Transfer. (Source: Interview at Telenor).

Over the counter services through Easypaisa Shop: Using the OTC channel Easypaisa customers can only use four products: Money Transfer service and Utility Bill payments, consumers could send and receive money to and from family, friends, etc from any Easypaisa shop in the most efficient, secure and convenient way. They did not have to own a Telenor connection, nor did they need to have a mobile phone. The best thing about the service was that any person in Pakistan could use this product and that no registration was required!

Bill payment: The Easypaisa bill payment service provided a person with a hassle free system and a secure way to pay electricity, gas, telephone, and water and internet bills. A person could easily pay utility bills from the nearest Easypaisa shop, Telenor franchise, Telenor Sales \& Service Center or Tameer Microfinance Bank branch.

International Home Transfer: Easypaisa International Home Transfer allowed individuals to receive money from over 80 countries through any sending partner. A Telenor connection was not required for this service and it was absolutely free!

Easyload: Now with Easypaisa Mobile Account one could purchase prepaid balance and pay postpaid bills any time anywhere from own mobile phone. This was an alternate recharge channel for the customers and one of its kind in the industry. This service was made available to all Telenor customers possessing Easypaisa Mobile Accounts.

\section{The Easypaisa Marketing Mix}

Pricing: The pricing of money transfer was based on slabs of amounts to be transferred. Moreover, to counter terrorist financing issues, there were two restrictions in the system:

- CNIC was required to transfer money

- Restriction on maximum number of transactions and amount of transaction: Sending \& Receiving Transactional Limits were Rs.10,000 per month on a CNIC and a maximum of 3 transactions per CNIC in a month.

Table 4: Rates of Easypaisa

\begin{tabular}{|c|c|c|c|c|}
\hline Slab Star & Slab Ema & Charges & FED * & Total Charges \\
\hline 1 & 1ㅁㅁ & 51.72 & 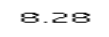 & $\mathrm{Rs} .5 \mathrm{a}$ \\
\hline 1 미 & こシロロ & $1 \square 345$ & $1 \equiv .55$ & R5. $1 \geq \square$ \\
\hline こБロ1 & 4ם & 155.17 & 24.93 & Rs. $19 \square$ \\
\hline $4 \square \square 1$ & Eロロロ & 2ロE.9口 & $\exists 3.1 \square$ & Rs. $24 \square$ \\
\hline Eם1 & 9ם므 & 259.2 & 41.39 & R5. \\
\hline :ロロ1 & 1ロロ & $31 \square .34$ & 49.65 & Rs. 35口 \\
\hline 1ロロロ1 & 1ラロロロ & ヨのこ.ロフ & $57.9 \Xi$ & Rs. $4 こ \square$ \\
\hline 1 ヨロロ 1 & 15ロロ & $41 \exists .79$ & $E \equiv .21$ & R5. $4: 8 \square$ \\
\hline
\end{tabular}

Sources: Telenor Website: All charges are subject to $16 \%$ FED 
The figure above shows the charges for CNIC to CNIC transfer. Other variants may have different charges.

Promotion: Since its introduction, Easypaisa had aggressively marketed its products. It was this aggressive marketing that enabled such a quick penetration of Easypaisa. The addon factors that were promoted as a part of this service were that it was:

○ Instant, Easy, Secure, and Simple.

The ads for Easypaisa focused not on the features or attributes, rather on the benefits that were to be gained from it. These factors were attractive for the target audience.

Placement: The placement of Easypaisa is what made it unique from its traditional counterpart banks. After 60 years of strong growth in Pakistan, Habib Bank Limited had 1400 branches in Pakistan whereas within less than 5 years, there were 20,000 retail outlets that offered Easypaisa services in Pakistan. Franchising, however, was not an easy option. Banks had never ventured into this territory due to reputational risk. However the distribution expertise of Telenor in managing agents played an important role and hence Easypaisa quickly developed in to an agent development model. Moreover, the potential target audience was more comfortable dealing with retailers whom they interacted with on a daily basis. Thus, this element of placement also distinguished Easypaisa from other banks.

\section{Easypaisa Customer Value Proposition (CVP)}

Easypaisa's CVP mainly focused on those gaps that existed between banking and financial sectors. Here is a comparison of gaps that existed in the traditional financial and telecom sector and how Easypaisa either responded to it or used it as its differentiating factor.

Table 5: Gap Analysis

\begin{tabular}{|l|l|}
\hline GAPS & RESOLUTION \\
\hline $\begin{array}{l}\text { Rural areas as well as lower class people in } \\
\text { Pakistan are primarily unbanked - thus } \\
\text { untapped market. The existing money } \\
\text { transfer system not efficient and not } \\
\text { reliable }\end{array}$ & $\begin{array}{l}\text { Their basic level of their banking need is } \\
\text { money deposit, making utility payments } \\
\text { and money transfer. Easy Paisa offers all } \\
\text { this through their local retailers/agent }\end{array}$ \\
\hline $\begin{array}{l}\text { Banking is too costly an activity to do in } \\
\text { rural areas 'in its current form' }\end{array}$ & $\begin{array}{l}\text { Use of franchising model that includes } \\
\text { commission based compensation for } \\
\text { retailers. These retailers also have their } \\
\text { other businesses being run on same } \\
\text { location, so fixed overhead is zero }\end{array}$ \\
\hline $\begin{array}{l}\text { Branches are costly to be built in rural } \\
\text { preas }\end{array}$ & $\begin{array}{l}\text { Easy Paisa is great value addition for } \\
\text { Telenor customers that has real utility. } \\
\text { Though, it allows non-Telenor users to do } \\
\text { the transactions too, but Telenor subscribers } \\
\text { have some additional facilities. }\end{array}$ \\
\hline
\end{tabular}




\begin{tabular}{|l|l|}
\hline $\begin{array}{l}\text { Revenue volatility from value added } \\
\text { services }\end{array}$ & $\begin{array}{l}\text { The value addition that Easy Paisa gives is } \\
\text { an eternal need for its target audience. Thus, } \\
\text { if successful, revenues are sustainable. This } \\
\text { is not fancy thing that will fade away. It's a } \\
\text { need. }\end{array}$ \\
\hline $\begin{array}{l}\text { Regulatory Requirements - money } \\
\text { laundering and know your customer } \\
\text { requirement }\end{array}$ & $\begin{array}{l}\text { Easy Paisa handled regulatory issues related } \\
\text { to money transfer by putting restriction on } \\
\text { number of transactions per CNIC per month } \\
\text { and amount of transaction per CNIC per } \\
\text { month }\end{array}$ \\
\hline
\end{tabular}

Source: Interviews within Tameer Bank and Telenor

Easypaisa made it feasible to reach the target audience and was portrayed to the lower class and working class as a product particularly tailored for their needs. All of its communications focused on what was most important for its target audience. It made people believe that Easypaisa was: instant, easy, secure, and simple.

Profit Formula: Since banks were not profitable in rural areas, Easypaisa had to develop a different model i.e. a model where it had to be creative in generating revenue and simultaneously reduce the cost so that it does not hamper their ability to meet the needs of its customers.

Revenue Model: Easypaisa along with its channel partners made money through the following modes:

- Account Registration Fee and Commission

- $\quad$ Cash Deposit Fees

- Money Transfer Fees

Regardless of the details, following are pricing features:

- $\quad$ Sharing revenue with retail outlets

- Special emphasis on retention commission to retail outlets

- $\quad$ Slabs for pricing

- Lesser prices from/ to mobile transfer account - a cross selling tactics

Cost Structure: The cost structure of Easypaisa was completely different from a bank. The major impediment for rural penetration was fixed overheads. Easy Paisa had virtually no or very little fixed overheads with respect to its distribution set up. When it was able to lower its fixed overhead, the profitability became a reality. Moreover, using a commission system also lowered the direct fixed cost i.e. that is the cost of salaries to bank staff. The money saved due to Easypaisa's distribution set up and the commission based system, was spent on advertisements and soon Easypaisa became a brand in itself.

Target Unit Margin: Though it operated on very low margins, Easypaisa's cost structure was so efficient that it was able to be profitable at lower margins. However even though analysts were, at the time, of the view that these margins may go down further in future it was certain that Easypaisa would be able to do continue operating successfully as the transaction velocity increases because it was a volume driven business. 
Key Processes: Though the process varied from product to product, the key to successful process management in this business was to keep it simple. To depict this, the process for money transfer which was Easypaisa's key product is shown in the following table: Money Transfer:

To Send Money: The Sender needs to bring and provide the following for a

- Their original and valid Nadra CNIC along with 1 Photocopy of the CNIC (Mandatory)

- Receiving person's valid Nadra CNIC Number (Mandatory)

- Their own mobile phone number (optional) and the receiver's mobile phone number (Optional)

- During sending, the Sender will be asked to enter a 5-digit secret pass-code on the Retailer's mobile phone. This pass-code should not be told to the Retailer, and only communicated to the Receiver

- If the Sender and Receiver mobile phone numbers are provided, both the Sender and Receiver will receive confirmation SMS messages containing the transaction information

Key Resources: The Key Resources for Easypaisa were none other than having well trained channel partners i.e. the retailers. Secondly, the banking knowledge and license and the most important is the GSM infrastructure which is the key for delivering the CVP.

\section{Future challenges}

At the Telenor head office Mr. Omar, the Head of Easypaisa Strategy, and his team were worried about the new players entering the mobile money market. The questions that arose were that how will these new entrants influence the competition in the market? Will the new players help the overall market to grow or not thereby benefitting Easypaisa as well? Or will they simply free ride on the hard work that Easypaisa had laid down including setting up agents? What will happen if the new players entering the market change the playing field from a one-to-one model to many-to-many model? What are the opportunities and risks that Easypaisa will have to encounter? What steps should they take to maintain their position as the market leader in what was now a very dynamic business sector? Omar wanted to develop his strategy before the Easypaisa strategy review meeting in April 2013.

At the Tameer Bank head office in Karachi, Mr. Nadeem and his team members were thinking about the future challenges and opportunities that will be available for Tameer Bank because of the success of Easypaisa. The following chief question that came to their minds was: how should Tameer Bank continue to take advantage from the Easypaisa business model? On the other hand, the microfinance industry experts were concerned about Tameer Bank's mission drift. They were apprehensive that in the near future, Tameer Bank will lose its vision and identity as a microfinance bank and will become a commercial bank due to the success of Easypaisa. This pressurized Mr. Nadeem into thinking on how he should respond to these rising concerns and position Tameer bank to manage and maintain its image as a microfinance bank. He wanted to present a clear $2014-2015$ strategy and action plan at the Tameer bank board meeting in Karachi in April 2013. 
Business Review - Volume 10 Number 1 January - June 2015

Exhibit A: Tameer Bank Financial Data and Analysis (2006 to 2011)

\begin{tabular}{|c|c|c|c|c|c|c|}
\hline $\begin{array}{l}\text { Balance sheet data (Rs } \\
\underline{1000)}\end{array}$ & Dec-06 & Dec-07 & Dec-08 & Dec-09 & Dec-10 & Dec-11 \\
\hline & Amount & Amount & Amount & Amount & Amount & Amount \\
\hline ASSETS & $1,229,863$ & $1,256,551$ & $2,256,611$ & $2,766,123$ & $5,299,934$ & $8,297,384$ \\
\hline $\begin{array}{l}\text { Cash and balances with } \\
\text { SBP \& NBP }\end{array}$ & 45,956 & 58,730 & 77,733 & 158,751 & 310,485 & 516,668 \\
\hline $\begin{array}{l}\text { Balances with other } \\
\text { banks/NBFIs/MFBs }\end{array}$ & $\mathbf{5 0 , 3 2 5}$ & 607,547 & 990,129 & 667,418 & 926,107 & $1,258,898$ \\
\hline $\begin{array}{l}\text { Money at call \& short } \\
\text { notice }\end{array}$ & 459,000 & & $\mathbf{0}$ & $\mathbf{0}$ & $\mathbf{0}$ & $\mathbf{0}$ \\
\hline $\begin{array}{l}\text { Investments }- \text { Net of } \\
\text { provision }\end{array}$ & 30,000 & 48,907 & 41,812 & 56,460 & 177,724 & 328,236 \\
\hline Gross Advances & 526,292 & 426,899 & 908,221 & $1,539,841$ & $3,096,044$ & $5,070,422$ \\
\hline Specific provisions & & $(43,058)$ & $(5,002)$ & $(3,550)$ & $(4,128)$ & $(5,978)$ \\
\hline General provisions & $(7,895)$ & $(5,022)$ & $(13,443)$ & $(23,043)$ & $(46,379)$ & $(10,147)$ \\
\hline Operating fixed assets & 78,106 & 94,994 & 120,004 & 156,463 & 188,609 & 252,810 \\
\hline Other assets & 48,079 & 67,554 & 137,157 & 213,783 & 651,472 & 886,475 \\
\hline LIABILITIES & 716,991 & 892,975 & $1,015,465$ & $1,636,157$ & $3,948,538$ & $6,821,545$ \\
\hline Borrowings & 222,998 & 222,998 & 339,923 & 309,939 & 661,608 & $1,801,725$ \\
\hline Current account & 78,671 & 91,034 & 158,227 & 570,682 & $1,150,329$ & $1,564,290$ \\
\hline Savings Deposits & 5,258 & 10,650 & 16,381 & 45,483 & 131,800 & 730,479 \\
\hline Term Deposits & 389,822 & 547,186 & 467,058 & 651,665 & $1,672,524$ & $2,217,760$ \\
\hline Sub-ordinated loans & & & & $\mathbf{0}$ & $\mathbf{0}$ & $\mathbf{0}$ \\
\hline Other Liabilities & 20,242 & 58,147 & 71,022 & 96,388 & 332,277 & 507,291 \\
\hline Deferred tax liabilities & & $(37,040)$ & $(37,145)$ & $(38,000)$ & $\mathbf{0}$ & $\mathbf{0}$ \\
\hline CAPITAL & 512,871 & $\mathbf{3 6 3 , 5 7 7}$ & $1,241,147$ & $1,129,966$ & $1,351,396$ & $1,475,839$ \\
\hline Paid-up capital & 600,000 & 600,000 & $1,690,408$ & $1,346,939$ & $1,346,939$ & $1,346,939$ \\
\hline Reserves & & & & 343,469 & 343,469 & 439,431 \\
\hline $\begin{array}{l}\text { Unappropriated/ } \\
\text { Unremitted profit }\end{array}$ & $(108,445)$ & $(269,931)$ & $(501,471)$ & $(610,563)$ & $(366,510)$ & $(328,144)$ \\
\hline $\begin{array}{l}\text { Surplus/ (Deficit) } \\
\text { revaluation of assets }\end{array}$ & 21,316 & 33,508 & 52,210 & $(1,121)$ & (288) & (18) \\
\hline Deffered Grants/Subsidies & & & & 51,242 & 27,786 & 17,631 \\
\hline Off balance sheet liabilities & & & & $\mathbf{0}$ & $\mathbf{0}$ & $\mathbf{0}$ \\
\hline & -1 & 2 & 1 & & & \\
\hline $\begin{array}{l}\text { Quarterly DATA } \\
\text { data (Rs 1000) }\end{array}$ & & & & & & \\
\hline
\end{tabular}


Business Review - Volume 10 Number 1

January - June 2015

\begin{tabular}{|c|c|c|c|c|c|c|}
\hline $\begin{array}{l}\text { Mark-up/Return/Interest } \\
\text { Earned on advances }\end{array}$ & 35,542 & 23,100 & 64,413 & 104,710 & 223,274 & 358,208 \\
\hline $\begin{array}{l}\text { Mark-up/Return/Interest } \\
\text { Earned on investments in } \\
\text { Government Securities }\end{array}$ & 261 & 1,043 & 1,193 & 2,610 & 6,311 & 14,872 \\
\hline $\begin{array}{l}\text { Mark-up/Return/Interest } \\
\text { Earned on placement with } \\
\text { other banks }\end{array}$ & 6,355 & 15,677 & 10,606 & 17,825 & 12,622 & 14,183 \\
\hline $\begin{array}{l}\text { Mark-up/Return/Interest } \\
\text { Earned on others }\end{array}$ & & & & $\mathbf{0}$ & $\mathbf{0}$ & $\mathbf{0}$ \\
\hline $\begin{array}{l}\text { Mark-up/Return/Interest } \\
\text { Expensed on } \\
\text { Deposits }\end{array}$ & 9,270 & 13,815 & & 929 & 1,720 & 10,931 \\
\hline $\begin{array}{l}\text { Mark-up/Return/Interest } \\
\text { Expensed on Term } \\
\text { Deposits }\end{array}$ & & & 17,254 & 24,771 & 52,622 & 73,811 \\
\hline $\begin{array}{l}\text { Mark-up/Return/Interest } \\
\text { Expensed on Borrowings }\end{array}$ & & & 15,984 & $\mathbf{0}$ & 18,481 & 58,363 \\
\hline $\begin{array}{l}\text { Mark-up/Return/Interest } \\
\text { Expensed on others }\end{array}$ & $\mathbf{0}$ & 7,756 & & 8,955 & $\mathbf{0}$ & $\mathbf{0}$ \\
\hline $\begin{array}{l}\text { Net Mark-up/ Interest } \\
\text { Income }\end{array}$ & 32,888 & 18,249 & 42,973 & $\mathbf{9 0 , 4 9 0}$ & 169,384 & 244,158 \\
\hline $\begin{array}{l}\begin{array}{l}\text { Provision } \\
\text { performing }\end{array} \\
\text { advances }\end{array}$ & 2,970 & 3,491 & $(1,244)$ & 3,073 & 5,022 & 1,968 \\
\hline $\begin{array}{l}\text { Provision for diminution in } \\
\text { the value of investments }\end{array}$ & & & & $\mathbf{0}$ & $\mathbf{0}$ & $\mathbf{0}$ \\
\hline $\begin{array}{l}\text { Provision Against Other } \\
\text { Assets }\end{array}$ & & & & $\mathbf{0}$ & $\mathbf{0}$ & $\mathbf{0}$ \\
\hline $\begin{array}{l}\text { Bad debts written off } \\
\text { directly }\end{array}$ & & 22,747 & $(1,019)$ & 1,568 & (453) & 3,091 \\
\hline $\begin{array}{l}\text { Total provisioning and } \\
\text { write-offs }\end{array}$ & 2,970 & 26,238 & $(2,263)$ & 4,641 & 4,569 & 5,059 \\
\hline Fees \& Commission & 6,754 & 6,009 & 5,702 & 16,633 & 48,313 & 98,841 \\
\hline Dividend Income & & & & $\mathbf{0}$ & $\mathbf{0}$ & $\mathbf{0}$ \\
\hline $\begin{array}{l}\text { Other Income (To be } \\
\text { specified) }\end{array}$ & 7,152 & 12,914 & 26,533 & 33,346 & 11,091 & 20,226 \\
\hline $\begin{array}{l}\text { Total non-markup/interest } \\
\text { Income }\end{array}$ & 13,907 & 18,923 & 32,235 & 49,979 & 59,404 & 119,067 \\
\hline $\begin{array}{l}\text { Administrative expenses } \\
\text { (without personnel) }\end{array}$ & 34,831 & 46,748 & 64,456 & $\mathbf{9 6 , 5 7 7}$ & 110,831 & 184,765 \\
\hline $\begin{array}{l}\text { Administrative Expensed } \\
\text { with Personal Expenses }\end{array}$ & 24,018 & 31,143 & 67,734 & 74,409 & 109,348 & 107,158 \\
\hline $\begin{array}{l}\text { Other provisions/write offs } \\
\text { (to be specified) }\end{array}$ & & & & & & 0 \\
\hline
\end{tabular}




\begin{tabular}{|l|l|l|l|l|l|l|}
\hline $\begin{array}{l}\text { Other charges (to be } \\
\text { specified, if material) }\end{array}$ & & & & 24,246 & $(247,505)$ & $(267)$ \\
\hline Total operating expenses & $\mathbf{5 8 , 8 4 9}$ & 77,891 & 132,190 & 195,232 & $(27,326)$ & 291,656 \\
\hline $\begin{array}{l}\text { PROFIT/LOSS) BEFORE } \\
\text { TAXATION AND } \\
\text { BEFORE EXTR } \\
\text { ORDINARY ITEMS }\end{array}$ & $(15,025)$ & $(66,957)$ & $(54,719)$ & $(36,958)$ & 254,468 & 66,243 \\
\hline $\begin{array}{l}\text { Extra ordinary/unusual } \\
\text { items (to be specified) }\end{array}$ & & & & 0 & 0 & 0 \\
\hline Subsidies received & & & & 22,446 & 2,923 & $(267)$ \\
\hline Taxation - Current & & & 1,263 & 0 & 0 & 5,470 \\
\hline - Deferred & & & & 0 & 0 & 75,173 \\
\hline $\begin{array}{l}\text { PROFIT/LOSS) AFTER } \\
\text { TAXATION }\end{array}$ & $(15,025)$ & $(66,957)$ & $(55,982)$ & $(36,958)$ & 254,468 & $(14,400)$ \\
\hline
\end{tabular}

\section{References}

http://www.itu.int/ITU-D/ict/statistics/at_glance/KeyTelecom.html

http://www.prb.org/Publications/Datasheets/2012/world-population-data-sheet/fact-sheetworld-population.aspx

http://www.telecomcircle.com/2011/01/the-mobile-payment-conundrum/

http://www.telenor.com.pk

http://www.pta.gov.pk

The Socio-Economic Impact of Mobil Financial Services: Analysis of Pakistan, Bangladesh, India, Serbia and Malaysia, April, 2012, the Boston Consulting Group, USA.

DAWN, 20 Feb, 2013

Interviews within Tameer Bank and Telenor

Telenor Official Reports and Interviews

Consider the world, apart from mankind. It is either static, or else changing in a gradual and apparently automatic rhythm... But man, in his brief, has transformed both the world and himself. His specific quality is purposeful change through thought. He is most truly alive when he thinks.

GilberHighet 